\title{
Excessive Follicle-stimulating Hormone Excretion and Production in Males with Untreated Congenital Adrenal Hyperplasia
}

\author{
SALVATORE RAITI, ${ }^{(27)}$ NOEL K. MACLAREN, AND FATIU A. AKESODE \\ Department of Pediatrics, University of Maryland School of Medicine, Baltimore, Maryland, USA
}

\begin{abstract}
Summary
The 24-hr urinary excretions of follicle-stimulating hormone (FSH) and luteinizing hormone (LH) were measured in seven males with untreated congenital adrenal hyperplasia. The patients aged 1-10 years had urinary FSH concentrations of 4.16.7 IU/day (normal = less than $2.5 \mathrm{IU} /$ day). Elevated levels of 13.6 IU/day were found in the 81-year-old patient. During suppressive steroid therapy, the FSH excretion fell to the normal range in the one so studied; therapy was reduced in two patients and their FSH excretion rose by $20-30 \%$ in a 4 -month period. The FSH production rate was 41.5 and $40.2 \mathrm{IU} / \mathrm{day}$ in the 1 and 6-year-old patients before therapy (these levels being at the upper limit of the normal range for adults). After 2.5 years of the FSH production rate in one of them fell to $10.3 \mathrm{IU} / \mathrm{day}$.

The excretion of $\mathrm{LH}$ was elevated for age and was 5.9 and 11.8 IU/day in the 1- and 6-year-old untreated patients (normal therapy, range $=$ less than $3 \mathrm{IU} /$ day). After suppressive therapy for 2.5 years, the LH excretion in the 1-year old fell only to 4.7 IU/day. In two patients, therapy was reduced for 4 months and the LH excretion actually fell from 5.1 to 2.9 and 10.0 to $7.4 \mathrm{IU} /$ day. Similarly, the 81-year-old untreated adult male showed an $\mathrm{LH}$ excretion of $16.4 \mathrm{IU} / \mathrm{day}$, which is lower than the normal adult range of 22.3-45.1 IU/day. The LH production rates in the 1- and 6-year-old patients before therapy were 166 and 141 IU/day, respectively both being lower than the range of 247.7464.5 IU/day found in normal adult males.
\end{abstract}

\section{Speculation}

The increased FSH production and excretion could be due to hypothalamic-pituitary stimulation by increased production of androgens or their precursors or from increased estrogens from the adrenal glands, or even to abnormal metabolites such as 17 . hydroxyprogesterone.

There is increased excretion of FSH in patients with untreated congenital adrenal hyperplasia $(\mathrm{CAH})$ as measured by bioassay $(2,4,22)$. This has neither been emphasized nor explained. Using radioimmunoassay we have confirmed these observations in five of seven patients with untreated CAH. This has been confirmed even more definitively by the measurement of the production rate of FSH in two of these patients.

\section{CASE STUDIES (TABLE 1)}

Seven patients were studied. Informed consent was obtained in each case.

\section{CASE 1 (HYPERTENSIVE TYPE OF CAH)}

This boy with 11-hydroxylase deficiency was previously reported because of his gynecomastia at one year of age (10.)
The 24-hr urinary excretion and production rates of FSH and LH were also measured at the time of diagnosis. Prednisone therapy was then begun. The FSH and LH studies were repeated at age 3.5 years while the patient was maintained on therapy. At that time, he had no pubic hair. His penis was $5 \mathrm{~cm}$ long and $2 \mathrm{~cm}$ in diameter. His testes measured $1.5 \times 1.0 \mathrm{~cm}$.

\section{CASE 2 (SIMPLE VIRILIZING CAH)}

This patient presented and was diagnosed at 6.5 years of age, when he had about 50 pubic hairs but no axillary or facial hair. His testes measured $3 \times 2 \mathrm{~cm}$ bilaterally and his penis was $4 \mathrm{~cm}$ long and $1 \mathrm{~cm}$ in diameter. Pubic hair and rapid growth in stature had been noticed at 3 years of age, but no medical care had been sought. After the diagnostic and gonadotropin studies, treatment with cortisone was initiated. Subsequently he was lost to follow-up.

\section{CASE 3 (SIMPLE VIRILIZING CAH)}

This boy had been diagnosed and treated at 9 months of age. At $311 / 12$ years, his cortisone therapy was reduced from 25 $\mathrm{mg}$ ( $5 \mathrm{mg}, 5 \mathrm{mg}$, and $15 \mathrm{mg}$ )/day to $10 \mathrm{mg} /$ day ( $5 \mathrm{mg}$ twice a day) for a 3-month period, after which time it was again increased to $25 \mathrm{mg} /$ day. Blood and 24-urine for gonadotropin studies were collected before reduction of therapy and each month for 3 months during reduced therapy.

\section{CASE 4 (SIMPLE VIRILIZING CAH)}

This boy was diagnosed at three years of age and treated. At age $124 / 12$ years, his prednisone therapy was reduced from $7.5 \mathrm{mg} /$ day ( $2.5 \mathrm{mg}$ three times a day) to $2.5 \mathrm{mg}$ daily for a $2-$ month period, was stopped completely for 1 month, and was then restarted at $7.5 \mathrm{mg} /$ day. Blood and 24-hr urine for gonadotropin studies were collected before therapy was reduced and also at monthly intervals. At this time he had about 50 pubic hairs but no axillary or facial hair. His penis was $6 \mathrm{~cm}$ long and his testes measured $2 \times 2 \mathrm{~cm}$ bilaterally.

\section{CASE 5 (SIMPLE VIRILIZING CAH)}

This 81-year-old man with excessive virilization was studied at the Veterans Administration Hospital in Baltimore because he was thought to have an adrenal tumor. He had never received therapy, had not married, and had not fathered any children, to our knowledge. Only urine studies were carried out.

\section{CASE 6 (SALT-LOSING CAH)}

This baby boy aged 1 month was admitted for undiagnosed hyponatremic dehydration. A 24-hr urine sample was collected for FSH and LH measurements prior to steroid therapy. 
CASE 7 (SALT-LOSING CAH) 6.

This baby boy aged 3 weeks was studied as described for case

\section{METHODS}

The urinary excretion of FSH and $\mathrm{LH}$ was measured by the method of Raiti and Blizzard (14). The production rates (PR) of FSH and LH were measured by the methods of Raiti $e t$ al. $(16,17)$. The plasma testosterone $(T)$ and $\Delta^{4}$-androstenedione $\left(\Delta^{4}\right)$ concentrations were measured by radioimmunoassay $(3$, 12).

\section{RESULTS (TABLE 2)} FSH

The 24-hr urinary excretions for cases 1 and 2 were elevated both for age and for the degree of sexual development and were within the range found in adult males (16). The PRs before therapy were at the upper limit of the normal adult range (15). When case $l$ was restudied after 2.5 years of therapy, his PR had dropped by $75 \%$ and his excretion was in the normal range for age (19). Case 5 had high FSH excretion (19). In cases 3 and 4, the FSH excretion on therapy was normal for age, but after 3 months of partial or no therapy, the FSH excretions increased in both. The FSH excretions in cases 6 and 7 appeared to be low, but normal control subjects were not available. The plasma FSH concentrations were normal for age and sexual development in cases 2-4 (18). We do not have controls for the others.
LH

The quantity of LH in the 24-hr urinary excretions in cases 1 and 2 were elevated for age, consistent with stage 2 or 3 of sexual development (1), but well below the normal adult range. The PRs before therapy were also below the normal adult range (17). After 2.5 years of therapy in case 1 , his PR and excretion had dropped slightly. The excretion in case 5 was well below the normal adult range. Before therapy was reduced, cases 3 and 4 showed normal LH excretion for age and sexual development (1), but both decreased after 3 months of inadequate therapy. In cases 6 and 7 the LH excretions were either low or normal but no matched controls were obtained. The plasma $\mathrm{LH}$ concentrations were normal for age and degree of sexual development except in cases 1,6 , and 7 , in whom the concentrations appeared to be elevated (8).

\section{PLASMA $T$ AND $\Delta^{4}$}

All plasma $T$ values were about $10-20 \%$ of normal adult concentrations (slightly higher in case 2 ). The plasma $\Delta^{4}$ concentrations were considerably elevated in cases 1 and 2 and were normal or low for adult males in the others.

\section{DISCUSSION}

Untreated $\mathrm{CAH}$ in childhood provides us with a unique abnormality in which the child is subjected to chronically raised plasma androgen concentrations of adrenal origin without contribution of testicular hormones. In three of our patients (cases 1,2 , and 5) this has resulted in greatly increased FSH excretion and considerable elevation in FSH production in the two so

Table 1. Clinical and laboratory results at times studied ${ }^{1}$

\begin{tabular}{|c|c|c|c|c|c|c|c|}
\hline \multirow[b]{2}{*}{ Patient } & \multirow[b]{2}{*}{$\mathrm{CA}$} & \multirow[b]{2}{*}{ Ht age } & \multirow[b]{2}{*}{ Skeletal age } & \multicolumn{2}{|c|}{ Urinary $17 \mathrm{KS}, \mathrm{mg} / 24 \mathrm{hr}$} & \multicolumn{2}{|c|}{ Plasma, $\mathrm{mlU} / \mathrm{ml}$} \\
\hline & & & & Patient & $\begin{array}{c}\text { Normal } \\
\text { range }\end{array}$ & FSH & LH \\
\hline 1 & $10 / 12 \mathrm{yr}$ & $110 / 12 \mathrm{yr}$ & $28 / 12 \mathrm{yr}$ & 3.0 & $1-2$ & 4.0 & 7.5 \\
\hline 2 & $66 / 12 \mathrm{yr}$ & $96 / 12 \mathrm{yr}$ & $100 / 12 \mathrm{yr}$ & 8.8 & $1-3$ & 8.0 & 3.0 \\
\hline 3 & $311 / 12 \mathrm{yr}$ & $310 / 12 \mathrm{yr}$ & $46 / 12 \mathrm{yr}$ & 2.1 & $0.5-2$ & 4.5 & 2.5 \\
\hline 4 & $124 / 12 \mathrm{yr}$ & $10 \quad 0 / 12 \mathrm{yr}$ & $125 / 12 \mathrm{yr}$ & 3.1 & $3-8$ & 5.0 & 5.0 \\
\hline 5 & $81 \mathrm{yr}$ & $126 / 12 \mathrm{yr}$ & Adult & 51.2 & $6-18$ & & \\
\hline 6 & $4 \mathrm{wk}$ & $7 \mathrm{wk}$ & Birth & 1.6 & $1-2$ & $<1$ & 6.0 \\
\hline 7 & $3 \mathrm{wk}$ & $10 \mathrm{wk}$ & $12 \mathrm{wk}$ & 7.6 & $1-2$ & $<1$ & 7.0 \\
\hline
\end{tabular}

1 See case descriptions. CA: chronologic age; 17KS: 17-ketosteroids. Normal range for plasma FSH: males less than 5 years $=<4 \mathrm{mIU} / \mathrm{ml} ; 5-8$ years $=4.2 \pm 0.7 \mathrm{mIu} / \mathrm{ml}, 12-13$ years $=5.8 \pm 2.0 \mathrm{mlU} / \mathrm{ml}$; adult $=7.4 \pm 1.9 \mathrm{mIU} / \mathrm{ml}$. Normal range for plasma LH: males less than 5 years $=$ $<3 \mathrm{mIU} / \mathrm{ml} ; 5-8$ years $=3.4 \pm 0.6 \mathrm{mIU} / \mathrm{ml} ; 12-13$ years $=6.8 \pm 2 \mathrm{mIU} / \mathrm{ml}$; adult $=10.9 \pm 4.0 \mathrm{mIU} / \mathrm{ml}$.

Table 2. FSH and LH excretion and PR: Plasma androgen concentrations ${ }^{1}$

\begin{tabular}{|c|c|c|c|c|c|c|c|c|}
\hline \multirow[b]{2}{*}{ Subject } & \multirow{2}{*}{$\begin{array}{c}\text { Steroid } \\
\text { replacement } \\
\text { therapy }\end{array}$} & \multirow[b]{2}{*}{ CA } & \multicolumn{2}{|c|}{ FSH, IU/24 hr } & \multicolumn{2}{|c|}{$\mathrm{LH}, \mathrm{IU} / 24 \mathrm{hr}$} & \multirow{2}{*}{$\begin{array}{l}\text { Plasma T, } \\
\mathrm{ng} / 100 \mathrm{ml}\end{array}$} & \multirow{2}{*}{$\begin{array}{l}\text { Plasma } \Delta \\
{ }^{4} \mathrm{ng} / 100 \mathrm{ml}\end{array}$} \\
\hline & & & Excretion & PR & Excretion & PR & & \\
\hline Normal males adult & None & $20-50 \mathrm{yr}$ & $8.5 \pm 3.6$ & $21.9-47.6$ & $22.3-45.1$ & $247.7-464.5$ & $575 \pm 150$ & $190 \pm 20$ \\
\hline \multicolumn{9}{|l|}{ Patient 1} \\
\hline $\mathrm{a}$ & None & $10 / 12 \mathrm{yr}$ & 6.2 & 41.5 & 5.9 & 166 & 154 & 378 \\
\hline b & Full & $36 / 12 \mathrm{yr}$ & 1.7 & 10.3 & 4.7 & 139 & & \\
\hline Patient 2 & None & $66 / 12 \mathrm{yr}$ & 6.7 & 40.2 & 11.8 & 141 & 246 & 576 \\
\hline \multicolumn{9}{|l|}{ Patient 3} \\
\hline $\mathbf{a}$ & Full & $311 / 12 \mathrm{yr}$ & 2.9 & & 5.1 & & & \\
\hline $\mathbf{b}$ & Partial & $42 / 12 \mathrm{yr}$ & 4.1 & & 2.9 & & 133 & 69 \\
\hline \multicolumn{9}{|l|}{ Patient 4} \\
\hline a & Full & $124 / 12 \mathrm{yr}$ & 6.4 & & 10.0 & & & \\
\hline $\mathbf{b}$ & Partial & $127 / 12 \mathrm{yr}$ & 7.6 & & 7.4 & & 59 & 31 \\
\hline Patient 5 & None & 81 & 13.6 & & 16.4 & & & \\
\hline Patient 6 & None & $4 \mathrm{wk}$ & 0.21 & & 1.1 & & 39 & 34 \\
\hline Patient 7 & None & $3 \mathrm{wk}$ & 031 & & 0.35 & & 144 & 98 \\
\hline
\end{tabular}

$1 \mathrm{a}$ and $\mathrm{b}$ refer to the first and to subsequent studies in each patient. CA: chronological age. Normal range for FSH excretion: $1-5$ years $=$ less than $2 \mathrm{IU} /$ day; $5-8$ years $=2.0 \pm 1.1 \mathrm{IU} /$ day; $12-13$ years $=5.7 \pm 2.8 \mathrm{IU} /$ day. Normal range for LH excretion. $1-5$ years $=$ less than $2 \mathrm{IU} /$ day; $5-8$ years $=2.3 \pm 0.8 \mathrm{IU} /$ day; $12-13$ years $=7.8 \pm 4.6 \mathrm{IU} /$ day . 
studied. This increased excretion was suppressible to the normal range by replacement corticosteroid therapy. The two cases ( 3 and 4 ) for whom therapy was reduced for 3 months both showed increased FSH excretion within that time. On the other hand, the LH excretions were normal in cases $1-4$ but well below the adult range in case 5. Interestingly, cases 3 and 4 showed decreased LH excretions (along with FSH increases) when therapy was reduced. The LH PRs were all well below the normal adult range.

We have also studied two males with idiopathic sexual precocity (unpublished data) in whom the increased androgens were of testicular rather than adrenal origin. We have found that the FSH and LH excretions and production rates are consistent with the degree of sexual development. In particular, the FSH PRs have been below or at the lower limit of the normal adult range.

It is interesting to speculate why and which of the adrenal steroids are responsible for the increased FSH production. Our findings in sexual precocity make it unlikely that the increased testosterone production is solely responsible. The high plasma $\Delta^{4}$ concentrations could be the stimuli responsible for increased FSH production. Such high $\Delta^{4}$ concentrations have been previously reported but no gonadotropin studies were done (20). Two other possibilities are the increased 17-hydroxyprogesterone or possible increased plasma estrogens. Neither were measured in this study. Increased urinary estrogens excretion have been reported by others in untreated patients $(5,6$, $23,25)$. Small doses of ethinyl estradiol $(0.02$ and $0.05 \mathrm{mg} /$ day) have produced a 2 -fold rise in urinary FSH excretion in women, whereas larger doses $(0.07$ and $0.1 \mathrm{mg} /$ day) produced no effect or slight suppression (24).

It is also feasible that where there is an increased production of $\mathrm{ACTH}$ (as in untreated CAH), overactivity of pituitary FSH production might also occur as postulated by Stevens and Goldzieher (22). Sohval and Soffer (21) drew attention to case records of adrenocortical hyperfunction and increased urinary gonadotropin excretion and Goldzieher and Green (7) reported strong evidence for the occasional coexistence of hyperadrenocortical state and polycystic ovaries. Similar pituitary gland overactivity is sometimes seen in children with untreated hypothyroidism and high plasma thyroid-stimulating hormone concentrations, who also show sexual precocity.

The FSH and LH excretions in the two neonates were low. Perhaps a much longer exposure to increased adrenal androgens and/or estrogens is needed before the FSH changes can occur. The plasma concentrations of FSH and $\mathrm{LH}$ in the patients did not show any marked change from normal and this has been previously reported by others $(9,11,13)$.

We conclude that in untreated $\mathrm{CAH}$ of long standing, increased FSH production and excretion is to be expected but the mechanism producing this is not fully clear.

\section{CONCLUSION}

These studies show that untreated patients with $\mathrm{CAH}$ have high FSH excretion and production rates are to be expected. After steroid therapy, the values fell to normal. When therapy was decreased, the FSH excretion rose again. The LH excretion was either slightly elevated or normal or low; and the LH production rates remained below the normal adult range. When therapy was reduced, the LH excretion fell, presumably because of suppression from increased testosterone produced by the adrenal gland. On the other hand, the reason for the elevation of FSH production was unclear. Since the only source of steroids in the younger children was from the abnormal adrenal glands (there being no significant testicular contribution at this age), either the adrenal androgens or adrenal estrogens or abnormal precursors such as 17-hydroxyprogesterone must be potent stimuli of FSH production.

\section{REFERENCES AND NOTES}

1. Baghdassarian, A., Guyda, H., Johanson, A., Migeon, C. J., and Blizzard, R. M.: Urinary excretion of radioimmunoassayable luteinizing hormone (LH) in normal male children and adults, according to age and stage of sexual develohment. J. Clin. Endocrinol. 31: 428 (1970)

2. Brown, P. S.: Human urinary gonadotropins. I. In relation to puberty. J Endocrinol., 17: 329 (1958)

3. DeLacerda, L., Kowarski, A., Johanson, A. J., Athanasion, R., and Migeon, C. J.: Integrated concentration and circadian variation of plasma testosterone in normal men. J. Clin. Endocrinol., 37: 366 (1973).

4. Escamilla, R. F.: Diagnostic significance of urinary hormonal assays: Report of experience with measurements of 17-ketosteroids and follicle stimulating hormone in the urine. Ann. Intern. Med., 30: 249 (1947).

5. Gabrilove, J. L., Nicolis, G. L., and Sohval, A. R.: Non-tumorous feminizing adrenogenital syndrome in the male subject. J. Urol., 110: 710 (1973).

6. Goldzieher, J. W.: Estrogens in congenital adrenal hyperplasia. Acta Endocrinol., 54: 51 (1967).

7. Goldzieher, J. W., and Green, J. A.: The polycystic ovary. I. Clinical and histologic features. J. Clin. Endocrinol., 22: 325 (1962).

8. Johanson, A. J., Guyda, H., Light, C., Migeon, C. J., and Blizzard, R. M.: Serum luteinizing hormone by radioimmunoassay in normal children. $\mathrm{J}$. Pediat., 74: 416 (1969).

9. Kirkland, J., Librik, L., and Clayton, G.: Serum gonadotropin levels in female adolescents with congenital adrenal hyperplasia. J. Pediat., 84: 411 (1974).

10. Maclaren, N. K., Migeon, C. J., and Raiti, S.: Gunecomastia with congenital virilizing adrenal hyperplasia ( $11 \beta$-hydroxylase deficiency). J. Pediat., 86: 579 (1975).

11. Molitor, J. L., Chertow, B. S., and Fariss, B. L.: Long-term follow up of a patient with congenital adrenal hyperplasia and failure of testicular development. Fertil. Steril., 24: 319 (1973).

12. Murphy, B. E. P.: Sephadex column chromatography as an adjunct to competitive protein binding assays of steroids. Nature New Biol., 232: 21 (1971).

13. Penny, R., Olambiwonnu, N. O., and Frasier, S. D.: Precocious puberty following trreatment in a 6 year old male with congenital adrenal hyperplasia: Studies of serum luteinizing hormone (LH), serum follicle-stimulating hormone (FSH) and plasma testosterone. J. Clin. Endocrinol., 36: 920 (1973).

14. Raiti, S., and Blizzard, R. M.: Measurement of immunologically reactive follicle stimulating hormone in human urine by radioimmunoassay. J. Clin. Endocrinol. 28: 1719 (1968)

15. Raiti, S., Blizzard, R. M., Penny, R., and Migeon, C. J.: Production rate of follicle stimulating hormone in adult males. In: W. R. Butt, A. C. Crooke, and M. Ryle: Gonadotropins and Ovarian Development, p. 185 (E. \& S. Livingstone, London, 1970.

16. Raiti, S., Blizzard, R. M., Penny, R., and Migeon, C. J.: Critical analysis of methods for estimating production rates of FSH. Acta Endocrinol., 80: 275 (1975).

17. Raiti, S., Foley, T., Penny, R., and Blizzard, R. M.: Measurement of the production rate of human luteinizing hormone using the urinary excretion technique. Metabolism, 24: 937 (1975).

18. Raiti, S., Johanson, A., Light, C., Migeon, C. J., and Blizzard, R. M. Measurement of immunologically reactive follicle stimulating hormone in serum of normal male children and adults. Metabolism, 18: 234 (1969).

19. Raiti, S., Light, C., and Blizzard, R. M.: Urinary follicle stimulating hormone excretion in boys and adult males as measured by radioimmunoassay. J. Clin. Endocrinol., 29: 884 (1969).

20. Rivarola, M. A., Saez, J. M., and Migeon, C. J.: Studies of androgens in patients with congenital adrenal hyperplasia. J. Clin. Endocrinol., 27: 624 (1967).

21. Sohval, A. R., and Soffer, L. J.: The influence of cortisone and adrenocorticotropin on urinary gonadotropin excretion. J. Clin. Endocrinol., 11:677 (1951).

22. Stevens, V. C., and Goldzieher, J. W.: Urinary excretion of gonadotropins in congenital adrenal hyperplasia. Pediatrics, 41: 421 (1968).

23. Tamm, J., Apostolakis, M., and Voigt, K. D.: The effects of ACTH and HCG on the urinary excretion of testosterone in male patients with various endocrine disorders. Acta Endocrinol., 53: 61 (1966).

24. Vorys, N., Ullery, J. C., and Stevens, V.: The effects of sex steroids on gonadotropins. Amer. J. Obstet. Gynecol. 93: 641 (1965).

25. Wilkins, L., Lewis, R. A., Klein, R., Gardner, L. I., Crigler, Jr., J. F. Rosemberg, E., and Migeon, C. J.: Treatment of congenital adrenal hyperplasia with cortisone. J. Clin. Endocrinol., 11: 1 (1951).

26. We thank Doctor B. Hamilton (Veterans Administration Hospital, Baltimore) for allowing us to study case 5 . We also thank Mr. Glen E. Taylor for his technical help with FSH and LH studies and NIAMDD for the immunochemical FSH and LH and their antisera.

27. Requests for reprints should be addressed to: S. Raiti, M.D., Department of Pediatrics, University of Maryland, School of Medicine, Baltimore, MD 21201 (USA).

28. Received for publication July $25,1976$.

29. Accepted for publication April 5, 1977. 